Prof. Krijgsman was born in Holland in 1901. After studying biology at the University of Utrecht, he became junior lecturer there in 1921, later being appointed lecturer. In 1928, after being awarded the degree of doctor of philosophy with distinction, he emigrated to Java to become head of the Veterinary Research Institute at Buitenzorg. He later combined this post with that of professor of medical zoology at Batavia. In 1935 he returned to Holland to study the physiological effects of insecticides for the Netherlands Council for Scientific and Industrial Research and to lecture at the University of Utrecht. In 1949 he accepted the post of senior lecturer in physiology, in the Zoology Department, University of Cape Town, later being appointed associate professor. At the beginning of 1959 he became the first head of the newly formed Sub-department of General Physiology.

In spite of heavy teaching duties, Prof. Krijgsman published at least one hundred and twelve original papers during his lifetime, wrote four books on zoology and contributed to six others. His wife, Mrs. Nel E. Krijgsman, was a great help to him in this respect, being not only a devoted companion but also undertaking duties as his research assistant. Prof. Krijgsman is, perhaps, best known for his studies on the physiology of the invertebrate heart and on the physiology of parasites, but, in fact, he pioneered research in many fields, and the whole subject of invertebrate physiology would have been the poorer had he turned his talents elsewhere. The world of science has lost an eminent research worker and an original thinker: the University of Cape Town has lost also a valued colleague and friend.

A. C. Brown

\section{Dr. E. de Barry Barnett}

Edward de Barry Barnete, who died on March 23 , will be greatly missed by his many former colleagues and students. He could truly be described as a character. He was held in great affection but was often unpredictable. His instructions to his executors were definitely that he did not wish any obituary notice to be published, but he left a summary of his life among his papers, realizing, no doubt, that it would not be possible to avoid such notice and desiring, as always, to be of help.

He was born on October 20,1886 , and educated at Malvern College and University College, London, graduating with first-class honours in chemistry in 1908. After holding some industrial appointments in the dyestuff and explosives industries, he went back to academic work and was appointed lecturer in organic chemistry at the Sir John Cass Technical Institute in 1919; eventually he became head of the Department and deputy principal, retiring in 1947 .

$\mathrm{He}$ was the author of a number of well-known books, the latest of which, Mechanism of Organic Chemical Reactions, was published in 1956.

His own summary of his life passes very lightly over much that was significant. It does not tell of the extent or the high quality of his published papers, numbering more than a hundred, chiefly in the field of anthracene chemistry. It does not indicate his rather lonely private life as a bachelor, isolated by his deafness in so many ways. It gives no idea of the extent of his help to his students. He had an uncanny knack of selecting as junior laboratory staff those applicants who had the ability to advance. Barnett would teach them himself, at the same time often arranging and paying privately for other tuition to make good defects in their earlier education. Having got them over these hurdles, he would see that they lacked no help in gaining their degrees. There is no way of assessing the generous financial assistance that Barnett gave to so many students in days when grants from public funds were less common than they are now.

He was greatly handicapped by his deafness. His well-known "What?" with his hand cupped to his ear and his "You see what I mean to say", said in the loudest of tones, without any basis for uncertainty and not infrequently to the discomfort of those who overheard his criticism of them, remain as vivid memories. But at all these times, even when he criticized both his students and those in authority, there was a humorous twinkle in his eye and an underlying kindness in all he did.

Sir John Cass College was to him a life-time interest. He worked selflessly for its development throughout the whole of his teaching career. During the War, when much of the building was severely damaged by bombing and fire, he continued his teaching there, chiefly with classes at week-ends and by correspondence. He took more than his full share of fire-watching, spending his nights on the roof to make sure that his deafness did not cause him to miss any incidents that might have escaped his immediate attention had he been in a less-exposed position.

He is remembered by his many friends with a deep sense of loss and also with appreciation of the contribution he made not only to the advancement of chemistry but also to the development of the 'Cass'. His sincere care for the well-being and interests of his many students will not be forgotten. A. M. W ARD

\section{Mr. W. E. Lawrence}

The death on April 16 of Mr. W. E. Lawrence came as a great shock to his many friends and admirers who have, from time to time, received his help and been regaled with his varied experiences during his forty-three years of service in the Prosectorium of the Zoological Society of London.

William Edward Lawrence was born May 1, 1900, the son of a London milk-roundsman; his mother was Welsh, but "Billy", as he was affectionately known, was himself-both in physical appearance and temperament-a typical Cockney, with his ready wit, quick repartee, irrepressive sense of humour and rich fund of experiences.

Lawrence received an elementary school education at Princess Road School, Regent's Park (1904-14). Here he proved a good scholar, reaching the highest standard. Under the influence of his teacher, a Mr. Dakin, a Zoo addict, Lawrence's interests were early channelled towards animals and he made many visits with his teacher to the neighbouring Zoological Gardens. Apparently it was through Dakin's influence that "Billy" was recommended to the post in the Society's Gardens when, as was customary at that time, he left school at the age of fourteen.

He entered, the 'dead house', as it was then called, as prosector's boy and was placed under the direction of the prosector's assistant, Mr. C. H. Hicks, from whom Billy learned dissection, injection and the preparation of skeletal material, albeit employed mainly on menial tasks until Hicks' promotion to superintendent's assistant in 1925, when Lawrence 